\title{
Spring Migration of Eiders and Other Waterbirds at Point Barrow, Alaska
}

\author{
DOUGLAS A. WOODBY ${ }^{1}$ and GEORGE J. DIVOKY ${ }^{2}$
}

\begin{abstract}
Birds migrating along the flaw lead at Point Barrow, Alaska were observed from 6 May to 4 June 1976. Little migration occurred until 25 and 26 May, when winds shifted from northeasterly to southwesterly and widened the lead. King Eiders (Somateria spectabilis) were the most abundant migrant; their movements were greatest with southwesterly (following) winds and between 1200 and 1800 h (Alaska Daylight Savings Time). On 26 May 360000 King Eiders passed within a 10-hour period. Ninety percent of the migrant Glaucous Gulls (Larus hyperboreus) moved east by 25 May. Common Eiders (Somateria mollissima) and Oldsquaw (Clangula hyemalis) were most abundant in early June and the bulk of their migration probably occurred after 4 June. Male King Eiders passed mostly in May while females were more common in June, suggesting that this species delays pair bonding until the latter part of their migration. This strategy necessitates an early migration and introduces the risk of possible starvation due to late spring freezing in the high Arctic.
\end{abstract}

Key words: waterbirds, eiders, King Eiders, Somateria spectabilis; Glaucous Gulls, Larus hyperboreus; Common Eiders, Somateria mollissima; Oldsquaw, Clangula hyemalis; migration

RÉSUMÉ. On a observé du 6 mai au 4 juin 1976, des oiseaux en migration le long du chenal côtier à la point Barrow en Alaska. Peu de migration eut lieu avant les 25 et 26 mai, lorsque la direction du vent changea du nord-est au sud-ouest, élargissant le chenal. Les eiders respectables (Somateria spectabilis) étaient les migrateurs les plus abondants, apparaissant en plus grands nombres suivant les vents du sud-ouest lorsque ceux-ci soufflaient, et surtout entre $12 \mathrm{~h}$ et $18 \mathrm{~h}$ (heure avancée de l'Alaska). Quatre-vingt-dix pour cent des goélands bourgmestres (Larus hyperboreus) avaient volé vers l'est avant le 25 mai. Les eiders communs (Somateria mollisima) et les canards à longue queue (Clangula hyemalis) étaient plus abondants tôt en juin et la majeure partie de leur migration eut lieu probablement après le 4 juin. Les eiders respectables mâles survolaient surtout en mai, tandis que les femelles passaient plutôt en juin, ce qui suggère que l'accouplement de cette espèce ne s'effectue qu'à un stade plus tardif que leur migration. Cette stratégie nécessite une migration plus tốt et présente le risque d'inanition dâ au dégel tardif printannier dans l'Arctique boréal.

Mots clés: oiseaux marins, eiders, eider respectable, Somateria spectabilis; goéland bourgmestre, Larus hyperboreus; eider commun, Somateria mollisima; canard à longue queue, Clangula hyemalis; migration

Traduit pour le journal par Maurice Guibord.

\section{INTRODUCTION}

Few birds are present in the Beaufort and Chukchi seas from November through late May, during which time ice cover is nearly complete. In late April or early May a lead (linear area of open water) develops from the eastern Bering Sea north through the Chukchi Sea to Point Barrow (Shapiro and Burns, 1975; Fig. 1). This is a flaw lead, which forms when the free-floating pack ice separates from the more stable shorefast ice. The lead ceases to be a flaw lead north of Point Barrow and continues east and northeasterly as a series of small leads in the pack ice of the Beaufort Sea.

The formation of this flaw lead is an annual occurrence, the first major event in the decomposition of the pack ice in the Arctic Ocean off northern Alaska. A number of marine bird and mammal species use the lead as a migration pathway to breeding grounds in northern Alaska and the Canadian Arctic. The King Eider is the most abundant of these, moving northeast past Point Barrow in phenomenal numbers in the spring, and returning westward in mid- to late summer after breeding.

Four major studies of the summer return migration past Point Barrow have documented the huge numbers and westward passage of King Eiders (Thompson and Person, 1963; Johnson, 1971; Flock, 1973; Timson, 1976). Less extensive studies have been made of the pre-breeding rush of birds past Point Barrow (Murdoch, 1885; Myres, 1958;
Johnson, 1971; Flock, 1973; Flock and Hubbard, 1979; Brueggeman, 1980). Recent studies have dealt with migration along the Beaufort Sea coast east of Point Barrow (Richardson et al. 1975; Johnson and Richardson, 1981; Richardson and Johnson, 1981). We conducted observations during the spring of 1976 at the lead's edge north of Point Barrow to assess the magnitude and timing of the spring migration along the lead.

\section{METHODS}

Observations were made at the edge of the flaw lead $6 \mathrm{~km}$ offshore of Point Barrow from 6 May to 4 June 1976 (Fig. 1). On 28 and 29. May the shorefast ice was unstable and hazardous for travel so the migration was viewed from the Point Barrow spit. After 4 June breakup of shorefast ice prevented further observations at the lead's edge. Nearly all observations were made by one observer (DAW) with less than three hours of assistance from others. Observations at the lead were from ice mounds $2-4 \mathrm{~m}$ high using $7 \times 35 \mathrm{~mm}$ binoculars; this allowed censusing of migrants up to $1 \mathrm{~km}$ away from the observing site.

Continual sunlight allowed observation periods to be staggered throughout the 24-hour clock so that all parts of the day received approximately the same effort; this was not done rigorously but in an opportunistic manner dependent on weather. The average census period was 2 h $25 \mathrm{~min}$ ranging from $15 \mathrm{~min}$ to $12 \mathrm{~h}$ with a total of nearly $129 \mathrm{~h}$

\footnotetext{
${ }^{1} 1054$ Bay View Cemetery Road, Mt. Vernon, Washington 98273, U.S.A.

${ }^{2}$ College of the Atlantic, Bar Harbor, Maine 04609, U.S.A.
} 

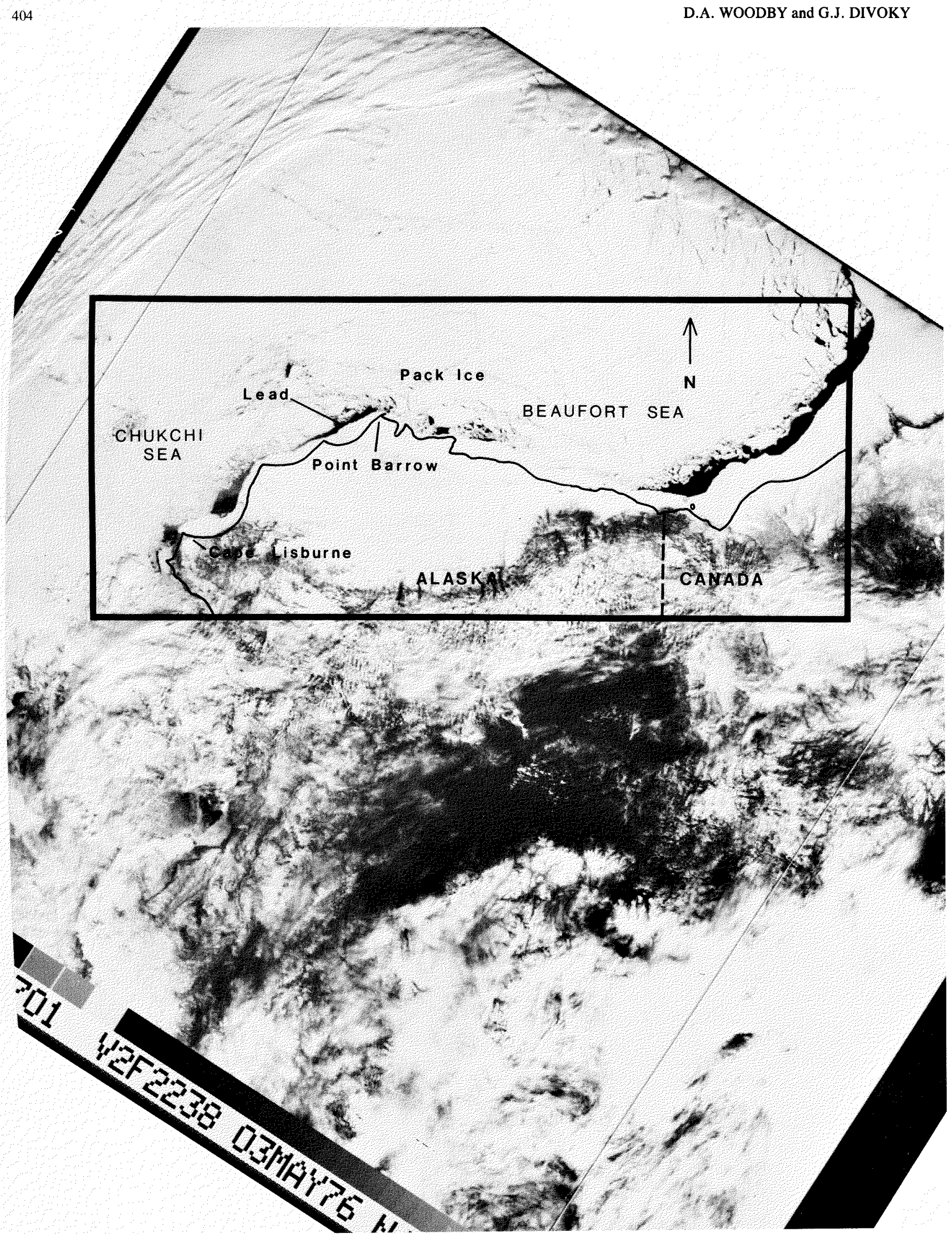

FIG. 1. Satellite imagery of northern Alaska, 3 May 1976, showing the flaw lead from Cape Lisburne to Point Barrow. 
( $n=53$ periods). Censusing was rarely done during periods of dense fog or blowing snow. Observations after 4 June were made from shore and were incidental to other work.

An attempt was made to count and identify all birds seen flying seaward of the shorefast ice; some inland migrants may have been missed. Migrants flying west or southwest were deducted from totals of northeast-bound migrants, and birds flying perpendicular to the lead were not included in the totals. Few birds were seen moving in directions other than northeast. Notes were made on the numbers, sex, plumage, and flight direction of each flock. Air temperature, wind speed, and wind direction were measured for all observation periods using handheld instruments. The U.S. Weather Bureau gathered hourly weather data at Barrow $18 \mathrm{~km}$ to the southwest.

\section{RESULTS AND DISCUSSION}

\section{Numbers of Migrants}

Twenty-one species of birds were seen at the lead from 6 May to 4 June (Table 1). Before 16 May only Glaucous Gulls and Black-legged Kittiwakes were seen. These were often feeding at the edge of the ice and did not appear to be migrating. The bulk of waterfowl and land birds did not arrive until early June when more open water was present and tundra became exposed.

King Eiders, Common Eiders, Oldsquaw, and Glaucous Gulls were the most abundant migrants. The total seen, the maximum hourly rate, and a projected total passage of

TABLE 1. Birds observed at the flaw lead off Point Barrow, Alaska, between 6 May and 4 June 1976

\begin{tabular}{|c|c|}
\hline Species & Date first seen \\
\hline Yellow-billed Loon (Gavia adamsii) ${ }^{1}$ & 1 June \\
\hline Canada Goose (Branta canadensis) & 16 May \\
\hline Brant (Branta bernicla) & 1 June \\
\hline White-fronted Goose (Anser albifrons) & 16 May \\
\hline Oldsquaw (Clangula hyemalis) ${ }^{1}$ & $16 \mathrm{May}$ \\
\hline Common Eider (Somateria mollissima) ${ }^{1}$ & 17 May \\
\hline King Eider (Somateria spectabilis) ${ }^{1}$ & 16 May \\
\hline Spectacled Eider (Somateria fischeri) & 2 June \\
\hline Ruddy Turnstone (Arenaria interpres) & 29 May \\
\hline Dunlin (Calidris alpina) & 4 June \\
\hline Red Phalarope (Phalaropus fulicarius) & 4 June \\
\hline Pomarine Jaeger (Stercorarius pomarinus) & 26 May \\
\hline Glaucous Gull (Larus hyperboreus) & $6 \mathrm{May}$ \\
\hline Black-legged Kittiwake (Rissa tridactyla) ${ }^{1}$ & 6 May \\
\hline Thick-billed Murre (Uria lomvia) ${ }^{1}$ & 17 May \\
\hline Black Guillemot (Cepphus grylle) & 8 May \\
\hline Short-eared Owl (Asio flammeus) & 2 June \\
\hline White Wagtail (Motacilla alba) & 2 June \\
\hline Fox Sparrow (Passerella iliaca) & 23 May \\
\hline Lapland Longspur (Calcarius lapponica) & $26 \mathrm{May}$ \\
\hline Snow Bunting (Plectrophenax nivalis) & $26 \mathrm{May}$ \\
\hline
\end{tabular}

${ }^{1}$ Common offshore after the sample period. each of these four species is presented in Table 2 . Figure 2 illustrates their daily passage along the lead from 6 May to 4 June.

TABLE 2. Numbers of migrant King Eiders, Common Eiders, Oldsquaws and Glaucous Gulls at the flaw lead off Point Barrow, Alaska, 6 May to 4 June, 1976

\begin{tabular}{lrrrc}
\hline \hline & $\begin{array}{c}\text { King } \\
\text { Eider }\end{array}$ & $\begin{array}{c}\text { Common } \\
\text { Eider }\end{array}$ & Oldsquaw & $\begin{array}{c}\text { Glaucous } \\
\text { Gull }\end{array}$ \\
\hline Total seen & 409353 & 10480 & 3542 & 691 \\
$\begin{array}{l}\text { Maximum } \\
\text { hourly rate }\end{array}$ & 37268 & 6342 & 1094 & 39 \\
Projected total $^{1}$ & 802556 & 153081 & 32141 & 3537 \\
\hline \hline
\end{tabular}

'The projected total is a sum of daily projected totals. These were computed by multiplying the average hourly rate of migration by 24 hours. A different method was used to project a total for King Eiders on 26 May when their migration peaked. On that date the total count during peak passage was added to the projected total for the remainder of the day.

King Eider. These were the most abundant migrants, accounting for $>95 \%$ of all birds seen. They were first seen passing northeastward on 16 May and thereafter flocks were common, but irregular. On 26 May a huge mass migration of at least 360000 King Eiders passed within a $10 \mathrm{~h}$ period (from 0400 to 1400) with a peak of 113000 between 1230 and 1300 . These came within a few hours after the onset of following winds from the southwest and relatively warm $\left(-1\right.$ to $\left.-2^{\circ} \mathrm{C}\right)$ weather. In 24 hours, a projected total of about 500000 had passed. These were predominantly males (84\%), in flocks ranging from several hundred to tens of thousands of birds. Large flocks of King Eiders continued to pass until the last day of observation at the lead, 4 June, when females were more common (65\%). Eiders, mostly females, continued to migrate at least until 15 June. During the 30-day sampling period a projected total of 800000 King Eiders migrated east past Point Barrow, and migration continued after systematic observations ceased. The return migration of adults and young in the summer has been estimated at one million birds (Thompson and Person, 1963).

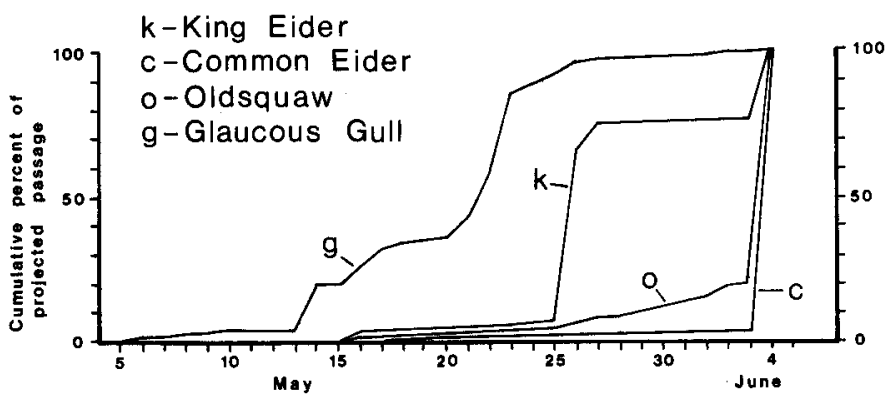

FIG. 2. Cumulative percent of projected total passage of King Eiders, Common Eiders, Oldsquaw, and Glaucous Gulls from 6 May to 4 June 1976. Migration of all four species continued after this period though systematic observations were not made. 
The King Eider is not a common nesting species in Alaska (Gabrielson and Lincoln, 1959), and most are found east of Dease Inlet, $40 \mathrm{~km}$ east of Point Barrow (Pitelka, 1974; Bergman et al., 1977). The majority of the migrants that enter the Beaufort Sea apparently continue their flight to arctic Canada where they are common breeders, particularly on Victoria Island where an estimated 800000 nest (Barry, 1968).

Common Eider. These large ducks were first seen at the lead on 17 May. They usually flew northeast in mixed flocks with King Eiders but were uncommon (projected total $=875$ ) until 4 June when $>10000$ were seen. It is possible that some Common Eiders were overlooked in the major King Eider passage of 26 May, but the bulk of the Common Eider migration occurred in June after most of the King Eiders had passed. Common Eiders nest singly and in small colonies along the coast and barrier island of the Beaufort Sea in Alaska, though most of the Common Eiders passing Point Barrow apparently breed in the Canadian Arctic, since a census of Alaskan Beaufort islands revealed only 420 nests (Divoky, 1978).

Oldsquaw. These migrated northeast in small flocks. They were more common in early June than in all of May with a projected total passage of 13000 as of 4 June. Approximately $60 \%$ of the Oldsquaws that were sexed were males, and this percentage remained fairly constant throughout the month of observations. Oldsquaws are ubiquitous as nesters in arctic coastal Alaska and Canada.

Glaucous Gull. These large northern gulls were present on the lead when observations began. The northeastward migration of adults was nearly complete before June and at least $60 \%$ of the adult migrants passed between 21 and 26 May. Only two immature Glaucous Gulls were seen; a two-year-old on 22 May on the Point Barrow spit and a three-year-old at the lead on 2 June. During the 30-day sampling period a projected total of 3500 Glaucous Gulls moved northeastward past Point Barrow. Unlike waterfowl migrations, the passage of these gulls is a regular movement of small numbers rather than pulses of large flocks. They were occasionally seen feeding at the ice edge and picking at scraps from bowhead whale (Balaena mysticetus) carcasses at native camps. They are common breeders in Alaska, and begin nesting very early relative to other arctic Alaskan birds. A colony of 300 gulls at Prudhoe Bay, $330 \mathrm{~km}$ east of Point Barrow, had some complete clutches on 12 June 1976 (Divoky, 1978).

The following marine species occurred in small numbers.

Loons. Loons were first seen on 23 May and continued passing until the end of observations with a total of 28 being seen. Peak migration was on 1 June and it appears most migration took place after 4 June. Only nine loons were identified to species. These were all Yellow-Billed Loons.

Geese. The majority of the spring migration of geese is probably inland, as only a few stragglers were seen along the coast. One Canada Goose and one White-fronted Goose were seen on $6 \mathrm{May}$, and one Brant was seen on 1 June. Five more White-fronted Geese were seen between 26 May and 4 June.

Spectacled Eider. A single male of this species was seen at Point Barrow on 2 June. Others may have been overlooked amidst the hordes of King and Common eiders, but the North Slope population is not large enough to suspect that a significant pulse passed unnoticed.

Red Phalarope. Two of these plankton feeders were seen at the lead edge on 4 June.

Pomarine Jaeger. Eight of these were seen off Point Barrow on 26 May, flying with the major wave of eiders.

Black-legged Kittiwake. One adult kittiwake was seen when observations began on 6 May, another on 17 May, and 6 more on 26 May, all heading northeast. While no breeding occurs in Alaska northeast of Cape Lisburne, non-breeding kittiwakes are common in the Beaufort Sea in summer (Watson and Divoky, 1974).

Thick-billed Murre. We saw 140 murres moving past Barrow after the first one was seen on 17 May. The bulk of these passed between 26 May and 2 June. These were apparently moving to the Cape Parry colony in Canada, although some may have been non-breeders from colonies to the south. They have been reported passing Wainwright, $150 \mathrm{~km}$ southwest of Barrow, in early May when no open water was present (Bailey, 1948).

Black Guillemot. This species winters as far north as Point Barrow in offshore leads (Nelson, 1969). They were present at the start of observations, but became more common on 26 May when 30 were seen. Migration into the Beaufort Sea was minimal, since the number seen moving northeast (56) was identical to the number seen moving southwest. The small but growing population of $>100$ pairs nesting in the Plover Island chain immediately east of Point Barrow constitutes $>90 \%$ of the Alaskan population north of Cape Lisburne.

Other species. Seven species of birds observed were considered to be stragglers at the lead with most of their migration occurring over land. Their presence at the lead's edge is likely a result of overshooting the beach, which is still snow-covered and rimmed by landfast ice in May and early June.

A few Ruddy Turnstones arrived in late April at the Barrow dump (Pat Reynolds, pers. comm.), and seven were seen over the lead on 29 May. Five Dunlin seen on 4 June heralded the arrival of many more to Barrow in the next few weeks. Two Short-eared Owls were observed over the lead on 1 June. They were quite common on the tundra during the snowmelt of early June 1976. White Wagtails are rare vagrants from nesting areas in Siberia and the southeastern Chukchi coast of Alaska. One was seen at the lead edge on 2 June. Two Fox Sparrows were seen at the lead edge, one on 23 May and another on 25 May; these were strays from shrub tundra nesting sites to 
the south. Lapland Longspurs were occasionally seen at the ice edge after the first one arrived there on 26 May. One male Snow Bunting visited the lead's edge on 6 May.

\section{Lead Dynamics as a Factor in Migration}

An open lead is probably requisite for the spring eider passage. While few eiders sit in the lead near Point Barrow, they probably are reluctant to move north until open water is present. Winds combine with a strong northeasterly moving current to create and maintain the lead from Cape Lisburne to Point Barrow, yet its width and extent undergo changes as often as the weather conditions shift. East and south winds widen the lead, whereas occasional north winds close or narrow it. Very cold temperatures may cause the lead to freeze over, whereas warmer temperatures usually associated with southerly winds cause the ice to melt.

The first warm weather $\left(-1-2^{\circ} \mathrm{C}\right.$ maximum) on 26 May 1976 followed north and east winds and cold temperatures $\left(-6^{\circ} \mathrm{C}\right.$ mean maximum from 21 to 24 May) that had narrowed and partially frozen the lead. Southwest winds and warm weather opened the lead, brought eiders, and heralded the onset of spring.

\section{Effects of Wind on Migration}

Many birds species show a strong penchant for migrating with following winds for various reasons (Richardson, 1978). Flock and Hubbard (1979) associated changes in barometric pressure preceding changes in wind direction with movements of King Eiders through the Bering Strait. At Komakuk in the south-central Beaufort Sea, Richardson et al. (1975) demonstrated that the magnitude of eastern migration in spring was greatest with westerly winds, rising pressure, and good visibility. This pertained to observations of Brant, Oldsquaws, Pomarine Jaegers, and Glaucous Gulls from 9 May to 10 June, but did not include King Eiders, as these are thought to migrate far offshore in the Beaufort Sea (Flock, 1973; Flock in Richardson et al., 1975). At Point Barrow, in late summer, Thompson and Person (1963) recorded large migrations of westbound eiders with following winds but suggested that eiders are insensitive to wind direction when wind speeds are $<14.5 \mathrm{~km} \cdot \mathrm{h}^{-1}$. Johnson (1971) and Timson (1976) both studied the summer migration and also concluded that more eiders fly with tailwinds and light winds, and that migration is dampened when head winds are strong. Conversely, Timson recorded stronger migrations of loons, gulls, and terns with headwinds.

Table 3 presents our data for intensity of eider movements relative to winds during the eastbound migration in the spring. Included are comparative data extracted from Johnson (1971:19) and Timson (1976:27), both from the westward migration. We employed Johnson's criteria that favorable winds come from the same direction as the birds (in this study within $89^{\circ}$ of southwest) while unfavorable winds are from any other direction. Neutral winds are those $<14.5 \mathrm{~km} \cdot \mathrm{h}^{-1}$ regardless of direction.
TABLE 3. Wind and eider migration intensity. Data for spring, 1976 and late summer, 1975 and 1970

\begin{tabular}{|c|c|c|c|}
\hline $\begin{array}{l}\text { Wind } \\
\text { Rating }\end{array}$ & $\begin{array}{r}\text { Spring } \\
1976^{1} \\
\end{array}$ & $\begin{array}{c}\text { Summer } \\
1975^{2} \\
\end{array}$ & $\begin{array}{c}\text { Summer } \\
1970^{3} \\
\end{array}$ \\
\hline \multicolumn{4}{|l|}{ Favorable } \\
\hline Birds per hour & 24106 & 314 & 730 \\
\hline $\begin{array}{l}\text { Hours of watch, } \\
\% \text { of effort }\end{array}$ & $15.8,15 \%$ & $11.5,17 \%$ & $75.5,69 \%$ \\
\hline $\begin{array}{l}\text { Total hours of } \\
\text { wind, }{ }^{5} \% \text { total }\end{array}$ & $48,11 \%$ & $75,15 \%$ & $954,70 \%$ \\
\hline \multicolumn{4}{|l|}{ Neutral } \\
\hline Birds per hour & 559 & 328 & 470 \\
\hline $\begin{array}{l}\text { Hours of watch, } \\
\% \text { of effort }\end{array}$ & $1.5,1 \%$ & $25.0,37 \%$ & $25.0,23 \%$ \\
\hline $\begin{array}{l}\text { Total hours of } \\
\text { wind, } \% \text { total }\end{array}$ & $24,5 \%$ & $234,47 \%$ & $285,21 \%$ \\
\hline \multicolumn{4}{|l|}{ Unfavorable } \\
\hline Birds per hour & 438 & 90 & 92 \\
\hline $\begin{array}{l}\text { Hours of watch, } \\
\% \text { of effort }\end{array}$ & $87.0,83 \%$ & $31.5,46 \%$ & $9.5,9 \%$ \\
\hline $\begin{array}{l}\text { Total hours of } \\
\text { wind, \% total }\end{array}$ & $384,84 \%$ & $185,37 \%$ & $130,10 \%$ \\
\hline
\end{tabular}

${ }^{1}$ This study, 16 May to 4 June. Approximately $95 \%$ of the eiders seen were King Eiders. Wind data are based on average for 24-h periods.

${ }^{2}$ Timson (1976), 27 August to 16 September. Neutral winds defined as $<9$ kts $\left(16.7 \mathrm{~km} \cdot \mathrm{h}^{-1}\right) .97 \%$ of the eiders were King Eiders.

${ }^{3}$ Johnson (1971), 13 July to 7 September. Data are for all waterfowl; 95\% eiders and about $90 \%$ King Eiders.

${ }^{4} \%$ effort indicates fraction of effort within a study.

${ }^{5}$ Total hours are all hours within the sampling period with each type of wind, with or without observation effort.

The spring eider migration in 1976 had far more birds per hour when following winds occurred than did the westbound return migration in 1970 and 1975 . This difference is coupled with a higher percentage of days with unfavorable winds in the spring of 1976 compared to conditions during the summer studies cited. 1976 had a relatively harsh spring, with $85 \%$ of the days having unfavorable wind conditions. In an average May (June data are similar) $45 \%$ of the winds are unfavorable, $42 \%$ are neutral, and $<13 \%$ are favorable (Brower et al., 1977).

The large pulse of migrants on 26 May 1976 occurred on the first warm spring-like day with southwesterly winds, suggesting that prolonged headwinds caused a build-up of birds farther to the southwest. A 19 May aerial survey at $150 \mathrm{~m}$ altitude over the lead southwest from Point Barrow to Cape Lisburne revealed at least 5000 eiders in eight flocks of 100 to 3000 birds. The lead had recently frozen over, and had closed or narrowed to $<100 \mathrm{~m}$ because north winds were pushing the pack ice south; only a few minor ice openings were left for the birds to occupy. These conditions were probably maintained by persistent northerly and easterly winds and cold temperatures during the following week, until the eider flight. This implies that concentrations of eiders were waiting south of Cape Lisburne and that they may have flown more than $480 \mathrm{~km}$ in one day. 
Years with milder wind conditions may have less dramatic but more prolonged, and possibly earlier, migration. Murdoch (1885) describes five great flights of King Eiders in 1882 between 12 May and 11 June, and six massive flights in 1883 from 17 May to 4 June, mostly on relatively warm days with west or southwesterly winds. He noted the first eiders on 27 April in 1882 with southerly winds.

\section{Time of Day and Migration Intensity}

We chose to test the possibility of diel variation in migration intensity throughout the 24-hour clock. Daylight was adequate for observations at all hours. Results are based on 6-h divisions (Table 4).

We found a marked peak of eider and Oldsquaw movement between 1200 and 1800 (ADST). This is true even though the date for the two most intense pulses of migrants, peaking at 1300 on 26 May and 1400 on 4 June, were deleted from this diel analysis. We did this to prevent subtle trends from being masked, yet the trends remain the same. The Glaucous Gull migration was strongest in late morning from 0600 to 1200 .

In the south-central Beaufort Sea in spring more Oldsquaws and Glaucous Gulls flew east during late morning and afternoon than in early morning (Richardson et al., 1975). This agrees roughly with our results. The difference in hourly rates between periods of the day was far greater in our study.

For the westbound migration at Barrow, Johnson (1971) found most eiders passing between midnight and 0600 . Thompson and Person (1963) and Timson (1976) both recorded more migrants between 1800 and midnight, although they did not sample the six-hour period after midnight. In all three of these summer studies the highest mean hourly rate of eider migration was only 2.4 times as great as the lowest mean rate for the same study. The corresponding ratio was nearly 200 to 1 in our study during the spring of 1976 , even when the two main pulses of eiders were excluded. This indicates that diel patterns may be more important for spring migrants. This is surprising considering that the spring migration occurs at a time of constant daylight whereas most of the fall migration occurs when the sun is below the horizon for part of the day.
Weather patterns may contribute to this daily rhythm, yet climatic data collected at Barrow from 1948 to 1974 (Brower et al., 1977) show no predictable diel variability in wind direction and only a minor trend in wind speed. More reliable cues such as the sun and its position may trigger movements, although the advantages of a diel migration rhythm are not clear.

\section{Inland Migration}

The paucity or lack of sightings at the lead for certain common arctic waterbirds indicates that they migrate north over the mainland rather than coastally. We saw few loons and Oldsquaws relative to the numbers seen passing Barrow in late summer and fall (Timson, 1976) and we saw far fewer Brant and jaegers than were seen heading eastward along the Canadian Beaufort Sea coast (Richardson et al., 1975). We did not see any Arctic Terns or Sabine's and Thayer's gulls, all of which nest to the east of Barrow and migrate west past Barrow in late summer and fall (Watson and Divoky, 1974). While it is possible that some migration of these species occurred over the lead after 4 June, it appears that most migration occurs inland.

Radar observations at Oliktok Point have shown a broad front of eastward migration over the North Slope extending at least $75 \mathrm{~km}$ south of the Beaufort Sea coast (Flock, 1973; Richardson and Johnson, 1981). Inland observers have noted pronounced northeastward and northward migrations of Brant and jaegers with lesser migrations of loons, Oldsquaws, Glaucous Gulls, and some Arctic Terns (Cade, 1955; Kessel and Cade, 1958; Irving, 1960, Palmer, 1962; Dean et al., 1976). These radar and visual observations have been summarized by Richardson and Johnson (1981), who conclude that the broad-front migration occurs because nearly complete ice cover in the Beaufort Sea makes the coast inconspicuous as a leading line and unremarkable as feeding or resting habitat for waterbirds.

The likelihood of eiders using the inland route is uncertain. Some eiders may take a shortcut south of Point Barrow as Myres (1958) noted eiders in spring migrating along the Inaru and Meade Rivers (75 km south of Point Barrow). Johnson (1971) reports eiders in spring heading overland at an inland site near Barrow and we observed

TABLE 4. Time and intensity of migration of King Eiders, Common Eiders, Oldsquaws and Glaucous Gulls, 6 May to 4 June, 1976

\begin{tabular}{|c|c|c|c|c|c|c|c|}
\hline $\begin{array}{l}\text { Period } \\
\text { of the day }\end{array}$ & $\begin{array}{c}\text { Hours of } \\
\text { effort }\end{array}$ & $\begin{array}{l}\text { Percent } \\
\text { of effort }\end{array}$ & $\begin{array}{c}\text { King } \\
\text { Eiders } \\
\text { per hour }\end{array}$ & $\begin{array}{c}\text { Common } \\
\text { Eiders } \\
\text { per hour }\end{array}$ & $\begin{array}{c}\begin{array}{c}\text { Eider } \\
\text { total }\end{array} \\
\text { per hour }\end{array}$ & $\begin{array}{l}\text { Oldsquaws } \\
\text { per hour }\end{array}$ & $\begin{array}{c}\text { Glaucous } \\
\text { Gulls } \\
\text { per hour }\end{array}$ \\
\hline $0000-0600$ & 20.75 & $16 \%$ & 0.5 & 3.9 & 4.3 & 8.4 & 2.7 \\
\hline $0600-1200$ & 33.08 & $26 \%$ & 51.1 & 1.8 & 52.8 & 16.4 & 8.2 \\
\hline $1200-1800$ & 47.67 & $37 \%$ & $846.4^{2}$ & 3.9 & $850.3^{2}$ & 56.0 & 3.2 \\
\hline $1800-2400$ & 27.22 & $21 \%$ & 159.5 & 0.3 & 159.8 & 3.2 & 1.2 \\
\hline
\end{tabular}

\footnotetext{
'Times are Alaska Daylight Savings.

${ }^{2}$ Data from peak passage of King Eiders between 1230 and 1300 on 26 May are not included.
} 
flocks passing northeastward over Barrow on 27 May. It is possible that some eiders fly much farther inland, nonstop and unseen, over Alaska to the eastern Beaufort Sea (Richarsdon and Johnson, 1981).

\section{Perils and Strategies of the King Eider Rush}

The sudden rush of King Eiders past Barrow with the first favorable winds is a risky venture in light of the unpredictability of open water to the east and the threat of a late freeze. Barry (1968) reported a major die-off of eiders in 1964 following a severe spring storm from 15-17 May. He estimated that 100000 eiders, roughly $10 \%$ of the Beaufort Sea population, were lost to starvation, and that similar catastrophes have occurred in other late-ice years. Unseasonally late spring and early fall freeze-ups have undoubtedly been important ultimate factors in determining timing of migration for arctic species. The projected total of 500000 eiders passing Point Barrow on 26 May 1976 is roughly one-half of the numbers estimated to use the Beaufort flyway, demonstrating that eiders tend to migrate with the first favorable weather. Oldsquaw reached a peak in migration at Barrow at least $\mathbf{1 0}$ days later than King Eiders. The difference in timing between these two species relates to differences in breeding strategies. Oldsquaws nest in the same tundra habitats as King Eiders and are almost as common in the eider's range (Bellrose, 1976:387). They begin to nest at about the same time and the incubation period of 26 days (Alison, 1975) is only a few days longer than the 23- or 24-day period of King Eiders (Parmelee et al., 1967). Unlike Oldsquaws, many male King Eiders preceded females in 1976, and thus courtship and pairing activities probably took place after passing Point Barrow. Courtship has been recorded during migration among resting flocks of King Eiders. This occurred once females caught up with earlier migrating males offshore of Cape Dorset, Baffin Island (Macpherson and McLaren, 1959). Drury (1961) saw courtship behavior near nesting areas on Bylot Island, and on Bathurst Island, Lamothe (1973) found that most King Eiders were paired when they came inland to a freshwater nesting area. They wait to make this move until the tundra clears of snow and ponds thaw (Salomonsen, 1950). Thus, there may be a lag period of two to three weeks between the time most eiders end their migration and the onset of nesting (Bellrose, 1976:370); this may be the time when pairing activity is common.

Differences in timing of pair formation demonstrate the function of the different migration patterns. Alison (1975) found Oldsquaws to be paired on arrival at breeding grounds in the Subarctic. He believes the breeding season is too short to accommodate the 30 days of courtship necessary for Oldsquaws to form pair bonds and still have adequate time to nest successfully. Thus pairing occurs in winter or in spring migration (Bellrose, 1976:391).

Delayed pairing after early migration by King Eiders means that this species congregates in the far north earlier than those species that pair prior to migration. This makes them more vulnerable to unseasonable freezing than later migrants and it is not clear what advantages this strategy affords them. Further studies of pre-egg laying biology, including pair formation and nest site competition within and between species, may shed light on this problem.

\section{ACKNOWLEDGEMENTS}

Support for this work came from the Arctic Project Office of the Outer Continental Shelf Environmental Assessment Program of the National Oceanic and Atmospheric Administration, Bureau of Land Management. We are indebted to the Naval Arctic Research Lab at Barrow, Howard Braham and crew of the National Marine Fisheries Service, and the Barrow whalers for their considerable field support. Special thanks go to William $\mathrm{H}$. Drury, P. Dee Boersma, and W. John Richardson for reviewing this paper.

\section{REFERENCES}

ALISON, R.M. 1975. Breeding biology and behavior of the Oldsquaw (Clangula hyemalis L.). Ornithological Monographs no. 18. $52 \mathrm{p}$.

BAILEY, A.M. 1948. Birds of Arctic Alaska. Colorado Museum of Natural History Popular Series 8. 317 p.

BARRY, T.W. 1968. Observations on natural mortality and native use of eider ducks along the Beaufort Sea coast. Canadian Field-Naturalist 82:140-144.

BELLROSE, F.C. 1976. Ducks, Geese, and Swans of North America. Harrisburg, PA: The Stackpole Co. and Washington, D.C.: Wildlife Management Institute. 544 p.

BERGMAN, R.D., HOWARD, R.L., ABRAHAM, K.F. and WELLER, M.W. 1977. Waterbirds and their wetland resources in relation to oil development at Storkersen Point, Alaska. Washington, D.C.: United States Fish and Wildlife Service Resource Publication 129. 38 p.

BROWER, W.A., Jr., SEARBY, H.W., WISE, J.L., DIZA, H.F. and PRECHTEL, A.S. 1977. Climatic Atlas of the Outer Continental Shelf Waters and Coastal Regions of Alaska. Asheville, NC: National Oceanic and Atmospheric Administration.

BRUEGGEMAN, J.J. 1980. Coastal occurrence of birds at Point Barrow, Alaska, in spring. Murrelet 61:31-34.

CADE, T.J. 1955. Records of the black brant in the Yukon Basin and the question of a spring migration route. Journal of Wildlife Management 19:321-324.

DEAN, F.C., VALKENBURG, P. and MAGOUN, A.J. 1976. Inland migration of jaegers in northwestern Alaska. Condor 78:271-273.

DIVOKY, G.J. 1978. Breeding bird use of barrier islands in the northern Chukchi and Beaufort seas. In: Environmental Assessment of the Alaskan Continental Shelf. Annual Reports of the Principal Investigators, Vol. 1. Boulder, CO: National Oceanic and Atmospheric Administration. 482-548.

DRURY, W.H., Jr. 1961. Observations on some breeding waterbirds of Bylot Island. Canadian Field-Naturalist 75:43-101.

FLOCK, W.L. 1973. Radar observations of bird movements along the arctic coast of Alaska. Wilson Bulletin 85:259-275.

and HUBBARD, J.D. 1979. Environmental studies at the Bering Strait. Appendix to: Drury, W.H. and Ramsdell, C. Ecological studies of birds in the Northern Bering Sea. In: Environmental Assessment of the Alaskan Continental Shelf. Annual Reports of the Principal Investigators, Vol. 1. Boulder, $\mathrm{CO}$ : National Oceanic and Atmospheric Administration.

GABRIELSON, I.N. and LINCOLN, F.C. 1959. Birds of Alaska. Harrisburg, PA: The Stackpole Co. and Washington, D.C.: Wildlife Management Institute. $922 \mathrm{p}$.

IRVING, L. 1960. Birds of Anaktuvuk Pass, Kobuk, and Old Crow. A study in arctic adaptation. U.S. National Museum Bulletin No. 217. $409 \mathrm{p}$. 
JOHNSON, L.L. 1971. The migration, harvest and importance of waterfowl at Barrow, Alaska. M.S. thesis, University of Alaska, College. $87 \mathrm{p}$.

JOHNSON, S.R. and RICHARDSON, W.J. 1981. Beaufort Sea barrier island-lagoon ecological process studies: final report, Simpson Lagoon. Part 3. Birds. In: Environmental Assessment of the Alaskan Continental Shelf. Final Reports, Biological Studies, Vol. 7. Boulder, CO: National Oceanic and Atmospheric Administration. 109-383.

KESSEL, B. and CADE, T.J. 1958. Birds of the Colville River, northern Alaska. Biological Papers of the University of Alaska No. $2.83 \mathrm{p}$.

LAMOTHE, P. 1973. Biology of King Eider (Somateria spectabilis) in a freshwater breeding area on Bathurst Island, N.W.T. M.S. thesis, University of Calgary, Alberta.

MACPHERSON, A.H. and MCLAREN, I.A. 1959. Notes on the birds of southern Foxe Peninsula, Baffin Island, Northwest Territories. Canadian Field-Naturalist 73:63-81.

MURDOCH, J. 1885. Birds. In: Ray, P.H. Report of the International Polar Expedition to Point Barrow, Alaska. Part. 4. Washington, D.C.: Government Printing Office. 104-128.

MYRES, M.T. 1958. Preliminary studies of the behaviour, migration and distributional ecology of eider ducks in northern Alaska, 1958. Interim Progress Report to The Arctic Institute of North America. 14 p.

NELSON, P.K. 1969. Hunters of the Northern Ice. Chicago: University of Chicago Press. $429 \mathrm{p}$.

PALMER, R.S. (ed.). 1962. Handbook of North American Birds. Vol. 1. Loons through Flamingos. New Haven, CT: Yale University Press. $567 \mathrm{p}$.

PARMELEE, D.F., STEPHENS, H.A. and SCHMIDT, R.H. 1967. The birds of southeastern Victoria Island and adjacent small islands. National Museum of Canada Bulletin 222:61.
PITELKA, F.A. 1974. An avifaunal review for the Barrow region and north slope of arctic Alaska. Arctic and Alpine Research 6:161-184.

RICHARDSON, W.J. 1978. Timing and amount of bird migration in relation to weather: a review. Oikos 30:224-272.

MORRELL, M.R. and JOHNSON, S.R. 1975. Bird migration along the Beaufort Sea coast: radar and visual observations in 1975. Beaufort Sea Technical Report 3c. Department of the Environment, Victoria, B.C. 131 p.

RICHARDSON, W.J. and JOHNSON, S.R. 1981. Waterbird migration near the Yukon and Alaskan coast of the Beaufort Sea. Part 1: Timing, routes, and numbers in spring. Arctic 34:108-121.

SALOMONSEN, F. 1950. The Birds of Greenland. Part I. Copenhagen: Ejnar Munksgaard. $608 \mathrm{p}$.

SHAPIRO, L.H. and BURNS, J.J. 1975. Major late-winter features of ice in northern Bering and Chukchi seas as determined from satellite imagery. University of Alaska Geophysical Institute Report 236:75-78.

THOMPSON, D.Q. and PERSON, R.A. 1963. The eider pass at Point Barrow, Alaska. Journal of Wildlife Management 27:348-356.

TIMSON, R.S. 1976. Late summer migration at Barrow, Alaska. In: Environmental Assessment of the Alaskan Continental Shelf. Principal Investigator's Reports, April - June 1976, Vol. 1. Boulder, CO: National Oceanic and Atmospheric Administration. 354-400.

WATSON, G.E. and DIVOKY, G.J. 1974. Marine birds of the western Beaufort Sea. In: Reed, J.C. and Sater, J.E. (eds.). The Coast and Shelf of the Beaufort Sea. Proceedings of a Symposium: Beaufort Sea Coast and Shelf Research. Montreal: The Arctic Institute of North America. 681-695. 